\title{
Kidney disease in natural infection by Ehrlichia canis in dogs
}

\section{Doença renal na infecção natural por Ehrlichia canis em cães}

\author{
Thaysa Felfili Ziliani ${ }^{1}$; Alessandra Ramos Castilho²; Daiane Poletto ${ }^{1}$; \\ Adriane Jorge Mendonça ${ }^{3}$; Valéria Régia Franco Sousa ${ }^{3}$; Valéria Dutra ${ }^{3}$; \\ Arleana do Bom Parto Ferreira de Almeida $^{3 *}$
}

\begin{abstract}
Canine monocytic ehrlichiosis, caused by the intracellular bacterium Ehrlichia canis, can affect different organs, including the kidneys, in different stages of infection, and kidney involvement is considered one of the main causes of death related to the disease. This study aimed to investigate the occurrence of kidney disease in dogs naturally infected with $E$. canis and to correlate antibody levels with the severity of renal disease. Serum concentrations of urea, creatinine, and proteins (albumin and globulin), along with urine concentration, urine gamma-glutamyl transferase, and urine protein levels, were evaluated in 60 dogs with $E$. canis infection diagnosed by polymerase chain reaction. The detection of anti-E. canis antibodies was also performed for each dog. Of the 60 dogs with E. canis infection, $73.33 \%$ presented anti-E. canis antibodies. Laboratory abnormalities consistent with renal disease were observed in 33 $(55 \%)$ infected dogs, and of these, $43.3 \%$ were in stage I chronic kidney disease. A positive correlation was observed between antibody levels and total plasma protein $(p=0.0332)$ and serum globulin $(p=$ 0.0057 ) levels. In this study, renal disease was observed on routine laboratory testing in $55 \%$ of dogs with monocytic ehrlichiosis; however, there was no correlation between the stage of renal disease and the antibody titer against $E$. canis.
\end{abstract}

Key words: Monocytic ehrlichiosis. Dog. Glomerulonephritis. Biomarker.

Resumo

A Erliquiose monocítica canina, causada pela bactéria intracelular Ehrlichia canis, pode acometer diferentes órgãos inclusive os rins, nas distintas fases da infecção, sendo considerada uma das principais causas de óbito relacionadas a essa doença. Este trabalho teve por objetivo investigar a ocorrência de doença renal em cães naturalmente infectados por E. canis correlacionando à gravidade da doença renal. Sessenta cães com infecção por E. canis diagnosticados pela reação em cadeia pela polimerase (PCR) foram avaliados a concentração sérica de ureia e creatinina, proteínas (albumina e globulinas), urinálise, gamaglutamil transferase urinária e proteinúria. Paralelamente foi pesquisado a presença de anticorpos anti-E. canis pelo ensaio imunoenzimático (dot ELISA). Dos 60 cães com infecção por $E$. canis, 73,33\% apresentaram anticorpos anti- E. canis, enquanto, 33 (55\%) cães apresentaram achados laboratoriais condizentes com doença renal, e destes $43,3 \%$ dos cães encontravam-se no estágio I da doença renal. Correlação positiva foi observada entre os níveis de anticorpos, globulina sérica $(\mathrm{p}=0,0057)$ e proteínas plasmáticas totais $(\mathrm{p}=0,0332)$. Neste estudo, a doença renal foi observada em

\footnotetext{
1 Discentes, Programa de Residência Uniprofissional em Medicina Veterinária, PRUMV, Universidade Federal de Mato Grosso, UFMT, Cuiabá, MT, Brasil. E-mail: thayza.ziliani@gmail.com; daiaepoletto@yahoo.com.br

2 Discente, bolsista de iniciação científica CNPq. Graduação em Medicina Veterinária, Universidade Federal de Mato Grosso, UFMT, Cuiabá, MT, Brasil. E-mail: ale.castilho@hotmail.com

3 Profs., Faculdade de Medicina Veterinária, FAVET, Universidade Federal de Mato Grosso, UFMT, Cuiabá, MT, Brasil. E-mail: adrianejorge.m@gmail.com; valeriaregia27@hotmail.com; valeriadutra.dutra@gmail.com; arleferreira@gmail.com

* Author for correspondence
} 
55\% dos cães com erliquiose monocítica, utilizando exames laboratoriais empregados na rotina clínica, sem correlação com o estadiamento da doença renal, apesar dos altos títulos de anticorpos contra $E$. canis.

Palavras-chave: Erliquiose monocítica. Cão. Glomerulonefrite. Biomarcador.

Canine monocytic ehrlichiosis is caused by the intracellular bacterium Ehrlichia canis of the family Anaplasmataceae and has a worldwide distribution. Infected dogs may present in the acute or subclinical phases, while those who do not clear the infection advance to the chronic phase (WANER; HARRUS, 2013).

Clinical signs induced by E. canis include fever, anorexia, weakness, lethargy, lymphadenomegaly, hemorrhagic disorders, neurologic abnormalities and chronic kidney disease. In the acute phase of renal injury induction, mild glomerulopathy may occur, evidenced by fusion of the podocyte processes, leading to proteinuria (CODNER et al., 1992; CASTRO et al., 2004). In the subclinical phase, basement membrane thickening, mesangial proliferation, focal segmental glomerulosclerosis, and synechia, associated with strong $\operatorname{IgM}$ and $\mathrm{C} 3$ positivity, suggest that the deposition of immune complexes may causerenal damage(CRIVELLENTI et al., 2015). Similarly, chronic glomerulonephritis may be induced by the deposition of immune complexes (IQBAL; RIKIHISA, 1994).

Furthermore, chronic stimulation caused by $E$. canis may induce silent glomerulonephrotic changes that contribute significantly to the development of severe renal disease in dogs (HEIENE et al., 2007; GOLDSTEIN et al., 2013). Therefore, this work aimed to investigate the occurrence of renal disease in dogs naturally infected by E. canis and to evaluate the correlation between antibody titer and the stage of renal disease.

Dogs of different breeds, ages, and sexes, examined at a university veterinary hospital in the city of Cuiabá, Mato Grosso, with clinical signs and amplification of E. canis DNA by nested polymerase chain reaction (PCR) (MURPHY et al., 1998) from blood and/or bone marrow samples, were included in the study, after obtaining written free and informed consent from the owners.

During the clinical evaluation of the dogs, blood samples were collected by cephalic or external jugular puncture into tubes with and without the anticoagulant ethylenediaminetetraacetic acid (EDTA). In addition, samples of the first urine of the day were obtained by urethral catheterization or cystocentesis.

A complete blood count was performed using the PocH-100iv Diff Automated Hematology Analyzer $\left(\right.$ Roche $\left.^{\circledR}\right)$, considering reference values determined by Jain (1993). Measurements of serum urea, creatinine, total protein, and albumin levels were performed using commercial kinetic and/or colorimetric (Gold Analisa ${ }^{\circledR}$ ) kits on a semiautomatic biochemical analyzer (SB 190$\mathrm{CELM}^{\circledR}$ ). The globulin level was calculated as the difference between total protein and albumin, and the albumin: globulin ratio was computed.

The urine samples were submitted to physicalchemical analysis and sedimentation, according to Kantek and Navarro (1996). In addition, urine creatinine and protein levels were measured using commercial kits (Gold Analisa ${ }^{\circledR}$ ) to establish the urine protein: creatinine (UPC) ratio and the urine gamma-glutamyl transferase (GGT): creatinine ratio.

Serum samples were processed for the detection of IgG antibodies using the ImmunoComb ${ }^{\circledR}$ Canine Ehrlichia semiquantitative method, according to the manufacturer's instructions.

For data analysis, the age groups were defined as follows: puppies (0 to 12 months), adults (13 to 60 months), and elderly dogs (over 60 months). Breeds were categorized as those with a defined breed (CRD) and those without a defined breed (SRD). 
For staging of the chronic renal disease (CKD), dogs were divided by serum creatinine level, urine concentration ability, and UPC, according to the International Renal Interest Society (IRIS, 2013) guidelines, as follows: stage 1 (creatinine $<1.4 \mathrm{mg}$ / $\mathrm{dl}$, non-azotemic animal, with isosthenuria and/or proteinuria of $\geq 0.5$ ), stage 2 (creatinine between 1.4 and $2 \mathrm{mg} / \mathrm{dl}$, mild azotemia), stage 3 (creatinine between 2.1 and $5 \mathrm{mg} / \mathrm{dl}$, moderate azotemia), and stage 4 (serum creatinine $>5 \mathrm{mg} / \mathrm{dL}$, severe azotemia). For analysis by Pearson's correlation between the antibody titer against $E$. canis and the stage of renal disease, the groups were subdivided as follows: Group 0 (dogs without renal disease), Group 1 (IRIS stage I renal disease dogs), and Group 2 (IRIS stage II, III, and IV renal disease dogs). The hematological, serum, and urine results were analyzed and were correlated with the antibody titer to E. canis by the Spearman or Pearson method, in the presence of normality, using Graph Pad Prism v.4.0 software.
During the study period, 60 dogs were diagnosed with monocytic ehrlichiosis. Of these, 39 (65\%) were males and 21 (35\%) females; 22 (36.7\%) were puppies, 27 (45\%) adults, and $11(18.3 \%)$ elderly; and $30(50 \%)$ were CRD and $30(50 \%)$ SRD. On the serological analysis, $16(26.7 \%)$ dogs had no antibodies to E. canis, 5 (8.3\%) had antibody titers of $1: 80,19(31.7 \%)$ had titers of $1: 320$, and 20 $(33.3 \%)$ had titers of $1: 640$.

The mean, standard deviation, and minimum and maximum values of the hematological findings and serum and urine biochemistry results are shown in Table 1. No statistically significant correlation was found between the antibody titers against E. canis and routinely used tests for the detection of renal disease $(p \geq 0.05)$ (Table 2$)$. However, a positive correlation with total plasma protein $(r=0.41)$ and serum globulin $(r=0.35)$ and a negative correlation with serum albumin $(\mathrm{r}=-0.27)$ and albumin: globulin ratio $(r=-0.45)$ were observed.

Table 1. Mean, standard deviation, and minimum and maximum values of the hematological findings and serum and urine biochemistry results of 60 dogs with monocytic ehrlichiosis.

\begin{tabular}{lccccc}
\hline \multirow{2}{*}{\multicolumn{1}{c}{ Parâmetros }} & \multicolumn{5}{c}{ Cães infectados por Ehrlichia canis $(\mathrm{n}=60)$} \\
\cline { 2 - 5 } & Média & Desvio & Mediana & Mínima & Máxima \\
\hline Hematocrit (\%) & 30,35 & 11,16 & 30,5 & 8,2 & 49 \\
Platelets $\left(10^{3} / \mathrm{ul}\right)$ & 132,2 & 122,5 & 82,0 & 01 & 459 \\
Total Plasma Protein (g/dl) & 7,25 & 1,46 & 7,0 & 3,6 & 12 \\
Urea (mg/dl) & 61,11 & 74,53 & 42 & 14 & 500 \\
Creatinine (mg/dl) & 1,35 & 1,73 & 0,9 & 0,4 & 9,3 \\
GGTU (UI/L) & 93,53 & 73,19 & 76 & 15 & 391 \\
GGT:CRU & 1,132 & 1,88 & 0,48 & 0,01 & 8,88 \\
UPC & 0,83 & 1,14 & 0,29 & 0,00 & 5,04 \\
Urinary Density & 1037 & 16,82 & 1042 & 1006 & 1096 \\
Total Serum Proteins & 6,68 & 1,87 & 6,70 & 2,60 & 13,70 \\
Albumin & 2,43 & 0,83 & 2,50 & 1,00 & 4,20 \\
Globulin & 4,24 & 1,77 & 3,95 & 1,60 & 12,10 \\
Albumin:Globulin & 0,65 & 0,34 & 0,57 & 0,13 & 1,90 \\
Sorology & 316,8 & 252,7 & 320 & 00 & 640 \\
\hline
\end{tabular}

GGTU: urine gamma-glutamyl transferase; GGT:CRU: urine gamma-glutamyl transferase (GGT): creatinine ratio; UPC: urine protein: creatinine (UPC) ratio; Albumin:Globulin: albumin: globulin ratio. 
Considering the IRIS classification, 33 (55\%) dogs had renal impairment in various stages as follows: $26(43.4 \%)$ in stage I, $1(1.6 \%)$ in stage II, $3(5 \%)$ in stage III, and $3(5 \%)$ in stage IV. The remaining $27(45 \%)$ had no kidney disease. A statistically significant correlation was observed between antibody titer and total plasma protein $(\mathrm{p}$ $=0.03, \mathrm{r}=0.54)$, total serum protein $(\mathrm{p}=0.01, \mathrm{r}$ $=0.45)$, and globulin concentration $(\mathrm{p}=0.00, \mathrm{r}=$ $0.56)$ in Group 0 and the albumin: globulin ratio (p $=0.01 ; \mathrm{r}=-0.48)$ in Group 1 .

Renal involvement in canine monocytic ehrlichiosis has been documented in natural and experimental infections (CODNER et al., 1992; LUCKSCHANDER et al., 2003). Renal damage has been associated with the elevated production of antibodies to E. canis, which induces the deposition of glomerular immune complexes (IQBAL; RIKIHISA, 1994; HEIENE et al., 2007; GOLDSTEIN et al., 2013). In this study, 73.3\% of the dogs with E. canis infection had antibody titers higher than 1:80; however, a positive and statistically significant correlation was observed only with total plasma protein concentration and serum concentration of globulin, and a negative correlation was observed with serum albumin concentration and albumin: globulin ratio. This significance was also present when analyzed by IRIS group. Such results may reflect the increase of gamma globulins present in the blood due to the antigenic stimulation provided by the bacterium, leading to an alteration in the albumin: globulin ratio and an increase in total plasma and serum proteins (Table 2).

Table 2. Correlation between the anti-Ehrlichia canis antibody titers and the hematological findings and serum and urine biochemistry results of 60 dogs with monocytic ehrlichiosis.

\begin{tabular}{lcc}
\hline Parâmetros & $\mathrm{R}$ & $\mathrm{p}$-value \\
\hline Hematocrit $(\%)$ & $-0,2511$ & 0,0529 \\
Platelets $\left(10^{3} / \mathrm{ul}\right)$ & 0,04104 & 0,7555 \\
Total Plasma Protein (g/dl) & 0,4117 & $0,0011^{*}$ \\
Urea (mg/dl) & 0,1058 & 0,4213 \\
Creatinine (mg/dl) & 0,1831 & 0,1615 \\
GGTU (UI/L) & $-0,1219$ & 0,3576 \\
UPC & 0,2364 & 0,0690 \\
GGT:CRU & $-0,05357$ & 0,6844 \\
Total Serum Proteins & 0,2103 & 0,1068 \\
Albumin & $-0,2754$ & $0,0332^{*}$ \\
Globulin & 0,3525 & $0,0057^{*}$ \\
Albumin:Globulin & $-0,4549$ & $0,0003 *$ \\
Urinary Density & $-0,2100$ & 0,1104 \\
\hline
\end{tabular}

* statistically significant ( $\mathrm{p}<0,05)$; GGTU: urine gamma-glutamyl transferase; GGT:CRU: urine gamma-glutamyl transferase (GGT): creatinine ratio; UPC: urine protein: creatinine (UPC) ratio; Albumin:Globulin: albumin: globulin ratio.

Approximately $20 \%$ of the infected dogs displayed hyposthenuria, uremia, increased urine GGT, and proteinuria, which indicate renal injury, although the values were not statistically significant. According to Pressler (2013), urine
GGT in dogs is considered not only an early marker of renal damage but also a persistent marker, which, together with hyposthenuria, may indicate a severe impairment of renal function (BARTGES, 2012). The observation of proteinuria in $43.3 \%$ of infected 
dogs in this study may be associated with constant stimulation of the immune system leading to glomerulonephritis (CRIVELLENTI et al., 2015). However, the increase in urine protein may also be due to increased inflammatory proteins associated with the infectious disease (BONFANTI et al., 2004). These proteins have a low molecular weight and can cross the glomerular membrane freely; however, the determination of the specific proteins is an aspect not pursued in this study.

Serum creatinine is the endogenous marker most commonly used to evaluate renal function (FREITAS et al., 2014). Although only $11.7 \%$ of the infected dogs had an elevated serum creatinine, $43.3 \%$ of the dogs were diagnosed with stage I CKD. These dogs were non-azotemic, but had some renal changes, such as loss of urine concentration and/or renal proteinuria; however, no significant correlation was observed between serum creatinine level and IRIS group. In $10 \%$ of dogs with E. canis infection, the azotemia was considered moderate to severe, indicating severe renal impairment (IRIS, 2013).

In this study, renal disease was observed on routine laboratory tests in $55 \%$ of dogs with monocytic ehrlichiosis, without a correlation between the stage of renal disease and the antibody titer against $E$. canis.

\section{Ethics Committee}

This research was approved by the Committee on Ethics in the Use of Animals (CEUA) of UFMT under $n^{\circ} 23108.075691 / 2015-97$.

\section{References}

BARTGES, J. W. Chronic kidney disease in dog and cats. Veterinary Clinics of North America: Small Animal Practice, Philadelphia, v. 42, n. 4, p. 669-692, 2012.

BONFANTI, U.; ZINI, E.; MINETTI, E.; ZATELLI, A. Free light-chain proteinuria and normal renal histopathology and function in 11 dogs exposed to
Leishmania infantum, Ehrlichia canis, and Babesia canis. Journal of Veterinary Internal Medicine, Philadelphia, v. 18, n. 5, p. 618-624, 2004.

CASTRO, M. B.; MACHADO, R. Z.; AQUINO, L. P.; ALESSI, A. C.; COSTA, M. T. Experimental acute canine monocytic ehrlichiosis: clinicopathological and immunopathological findings. Veterinary Parasitology, Amsterdam, v. 115, n. 1, p. 73-86, 2004.

CODNER, E. C.; CACEI, T.; SAUNDERS, G. K.; SMITH, C. A.; ROBERTSON, J. L.; MARTIN, R. A.; TROY, G. C. Investigation of glomerular lesions in dogs with acute experimentally induced Ehrlichia canis infection. American Journal of Veterinary Research, Chicago, v. 53, n. 12, p. 2286-2291, 1992.

CRIVELLENTI, L. Z.; SILVA, G. E. B.; BORINCRIVELLENTI, S.; DANTAS, M.; ADIN, C. A.; CIANCIOLO, R.; SANTANA, A. E. Glomerulopathies in dogs with erlichiosis -preliminary results. In: CONFERENCE WORLD SMALL ANIMAL VETERINARY ASSOCIATION - WSAVA, 40th, 2015, Bangkok. Proceeding... Bangkok: WSAVA Congress, 2015. p. 76.

FREITAS, G. C.; VEADO, J. C. C.; CARREGARO, A. B. Testes de avaliação de injúria renal precoce em cães e gatos. Semina: Ciências Agrárias, Londrina, v. 35, n. 1, p. 411-426, 2014.

GOLDSTEIN, R. E.; BROVIDA, C.; FERNANDEZDEL PALACIO, M. J.; LITTMAN, M. P.; POLZIN, D. J.; ZATElli, A.; COWGILl, L. D. Consensus recommendations for treatment for dogs with serology positive glomerular disease. Journal of Veterinary Internal Medicine, Philadelphia, v. 27, p. 60-66, 2013. Supplement 1.

HEIENE, R.; KRISTIANSEN, V.; TEIGE, J.; JANSEN, J. H. Renal histomorphology in dogs with pyometra and control dogs, and long term clinical outcome with respect to signs of kidney disease. Acta Veterinaria Scandinavica, London, v. 49, n. 13, p. 1-9, 2007.

IQBAL, Z.; RIKIHISA, Y. Application of the polymerase chain reaction for the detection of Ehrlichia canis in tissues of dogs. Veterinary Microbiology, Amsterdam, v. 42, n. 4, p. 281-287, 1994.

INTERNATIONAL RENAL INTEREST SOCIETY - IRIS. IRIS Staging of CKC. Seattle: IRIS, 2013. Available at: $<$ http://iris-kidney.com/pdf/n378.008-iriswebsite-staging-of-ckd-pdf.pdf $>$. Accessed at: 18 jun. 2017.

JAIN, N. C. Essencials of veterinary hematology. Philadelphia: Lea e Febiger, 1993. 417 p. 
KANTEK, G.; NAVARRO, C. E. Manual de urinálise veterinária. São Paulo: Varela, 1996. 96 p.

LUCKSCHANDER, N.; KLEITER, M.; WILLMANN, M. Renal amyloidosis caused by Ehrlichia canis. Schweizer Archiv Fur Tierheilkde, Zurich, v. 145, n. 10, p. 482-485, 2003.

MURPHY, G. L.; EWING, S. A.; WHITWORTH, L. C.; FOX, J. C.; KOCAN, A. A. Molecular and serologic survey of Ehrlichia canis, Ehrlichia chaffeensis, and E. ewingii in dogs and ticks from Oklahoma. Veterinary Parasitology, Amsterdam, v. 79, n. 4, p. 325-339, 1998.

PRESSLER, B. M. Clinical approach to advanced renal function testing in dogs and cats. The Veterinary Clinics of North America Small Animal Practice, Philadelphia, v. 43, n. 6, p. 1193-1208, 2013.

WANER, T.; HARRUS, S. Canine monocytic ehrlichiosis-from pathology to clinical manifestations. Israel Journal of Veterinary Medicine, Raanana, v. 68, n. 1, p. 12-18, 2013. 